\title{
Developing site scale projections of climate change in the Scottish Highlands
}

\author{
John Coll ${ }^{1,2, *}$, Stuart W. Gibb ${ }^{2}$, Martin F. Price ${ }^{3}$, John McClatchey ${ }^{2}$, John Harrison ${ }^{2}$ \\ ${ }^{1}$ Irish Climate Analysis and Research Units (ICARUS), Department of Geography, NUI Maynooth, Maynooth, Co Kildare, \\ Ireland \\ ${ }^{2}$ Environmental Research Institute, North Highland College, UHI Millennium Institute, Thurso, UK \\ ${ }^{3}$ Centre for Mountain Studies, Perth College, UHI Millennium Institute, Perth, UK
}

\begin{abstract}
With recent warming trends projected to amplify over the coming century, there are concerns surrounding the impacts on mountain regions. Despite these concerns, global (GCMs) and regional climate models (RCMs) fail to capture local scale-dependent controls on upland climates. A modelling framework combining climate model outputs and station data is presented and used to explore possible future changes to temperature with altitude in the Scottish Highlands. The approach was extended by modelling shifts in seasonal isotherm values associated with existing vegetation zones. To achieve this, temperature lapse rate models (LRMs) were applied to 1961-1990 baseline (BL) observed station data for selected stations in the eastern Highlands using seasonally representative lapse rate values (LRVs) derived from paired station values. Tests against 3 upland station records ranging from 663 to 1245 m indicated a credible model performance for the mean seasonal maximum $\left(\mathrm{T}_{\max }\right)$ and minimum $\left(\mathrm{T}_{\min }\right) \mathrm{BL}$ values evaluated. Following derivation of seasonal isotherm values for the present upper limit of vegetation zones via the LRMs, selected scenario data outputs from the corresponding Hadley Centre RCM (HadRM3H) $50 \times 50 \mathrm{~km}$ grid cells were used to project future changes to BL values via the LRMs. The findings suggest substantial shifts in the isotherm associated with each zone for the scenarios selected, with shifts in $\mathrm{T}_{\min }$ more marked than those for $\mathrm{T}_{\max }$, although substantial uncertainties remain. Following an exploration of the results for the region, we suggest that a refinement to the approach linked to a wider modelling effort incorporating other important controlling variables for upland species could inform future management initiatives for mountain areas more generally.
\end{abstract}

KEY WORDS: Maritime uplands $\cdot$ Lapse rates $\cdot$ Modelling $\cdot$ Conservation policy $\cdot$ Uncertainty Resale or republication not permitted without written consent of the publisher

\section{INTRODUCTION}

\subsection{Maritime upland climates and climate change}

Situated on the seaward western edge of northwestern Europe and subject to both maritime and continental influences, the climate of the Scottish Highlands and other UK uplands is typified by spatial and temporal variability. Superimposed on these synoptic controls, orographic effects produce a locally variable climate across the region. With more than $4500 \mathrm{~km}^{2}$ of the land surface being higher than $600 \mathrm{~m}$ above sea level, such altitudinal gradients of change are an im- portant control in the spatial pattern of climate across Scotland (Harrison \& Kirkpatrick 2001) and superimpose site-specific local controls on climate across the region (Coll et al. 2005, Coll 2007). Such high climate heterogeneity makes it difficult to characterise upland climates in the present, even before future changes are considered (Beniston 2003). Projected temperature changes are expected to be greater in mountains at higher northern latitudes than in those in temperate and tropical zones, with the rate of warming in mountain systems projected to be 2 to 3 times higher than that recorded during the 20th century (Nogués-Bravo et al. 2007). A further feature in some projections is 
that the anticipated warming of the next decades is expected to be more pronounced in northern hemisphere middle and high latitudes (Lean \& Rind 2009). However, while most climate models suggest this amplification of global warming for mountain regions, the observations indicate spatial variation in the amplitude of warming; e.g. areas near the annual $0^{\circ} \mathrm{C}$ isotherm in the extratropics exhibit the strongest warming rate (Pepin \& Lundquist 2008).

The variable climate of the Scottish uplands contributes greatly to their biodiversity, with a diverse mix of Atlantic, arctic, arctic-alpine and boreal elements occurring within a limited geographical area, and many species on the edge of their global distribution range (Birks 1997). Within this continuum of microclimates, most high-altitude plant species are adapted to slow growth with survival at a particular altitude determined by the altitudinal range over which a species is adapted, thus they may be unable to compete with upward migrating lowland species. However, landscape change in these sensitive upland environments results from a complex interplay between natural and anthropogenic factors.

There is particular concern that marginal maritime mountains may be especially vulnerable to the impact of climate changes (Ellis \& Good 2005, Orr et al. 2008). Scotland's highest mountains are located within the Atlantic biogeographic zone (European Commission 2005), and the relatively mild, wet climate renders species here particularly sensitive to changes in the winter and spring half year. While it might be expected that oceanic mountains would be buffered against climatic change by their more limited annual temperature range, by comparison with higher mountains such as the Alps, the lack of a nival zone limits the potential upward migration of species (Crawford 2001), at least for marginal arctic-alpine associations already near their southern range limit and snow bed associations. Additionally, if changes in climate lead to a reduction in the severity of the abiotic environment, this may lead to increased inter-specific competition associated with the possible invasion of species currently limited to lower elevations (Ellis \& Good 2005, Ellis \& McGowan 2006). An advancing tree line, for example, or a denser forest below the tree line would have important implications for the global carbon cycle (increasing the terrestrial carbon sink) and for the biodiversity of the alpine ecotone, possibly ousting rare species and disrupting alpine and arctic plant communities (Grace et al. 2002).

\subsection{Observed and projected changes for the uplands}

Evidence of recent climate change comes from observations at high-altitude sites across the globe, with observed changes including increased winter rainfall and rainfall intensity (Groisman et al. 2005, Malby et al. 2007), and temperatures increasing more rapidly than at lowland sites, particularly through increases in minimum (nocturnal) temperatures (Bradley et al. 2006). Changes have also been observed for UK uplands, including evidence of more rapid warming (Holden \& Adamson 2002) and marked precipitation changes (Barnett et al. 2006, Fowler \& Kilsby 2007, Maraun et al. 2008).

Going beyond these observed changes, projected climate changes are expected to have a greater impact on biota as the present century progresses (Berry et al. 2002, Thomas et al. 2004, Fischlin et al. 2007). Tree lines in many mountainous regions have already responded to recent temperature changes (MacDonald et al. 1998, Klasner \& Fagre 2002, Jump et al. 2007), with trees invading into meadows (Wearne \& Morgan 2001). The Norwegian mountain flora have shown analogous changes in species richness and altitudinal distributions over the last $70 \mathrm{yr}$ in response to a relatively small change of 0.4 to $1.2^{\circ} \mathrm{C}$ in annual temperature (Klanderud \& Birks 2003), and the high pine limit associated with the warm 20th century in the Swedish Scandes stands out as an anomaly in the Holocene record (Kullman 2002). For Scottish uplands, Ellis \& McGowan (2006) estimated that overall, a mean annual increase of $1^{\circ} \mathrm{C}$ would be associated with an isotherm shift of about 200 to $275 \mathrm{~m}$ uphill or 250 to $400 \mathrm{~km}$ of a move northwards. Similarly, Hill et al. (1999) estimated that a rise in mean temperature of $1.8^{\circ} \mathrm{C}$ by 2100 would equate to an altitudinal isotherm ascent of $300 \mathrm{~m}$ for an area such as the Cairngorms.

\subsection{Aims and objectives}

Here we sought to address some of the challenges associated with obtaining site-specific climate change impact assessments for priority habitats and species in maritime upland areas. Scale-dependent local controls, e.g. on climate in upland regions, are not adequately captured in the present generation of global and regional climate models (GCMs and RCMs, respectively) due to the relatively coarse resolution of the model grids. Therefore, until advances in climate system modelling improve the representation of localscale climate processes, there is a need to develop methods to better represent local projections of future changes to key climatic variables. One complication with using RCM outputs for impact studies in mountain regions relates to the terrain smoothing within the model; as a result of this, the elevation of specific sites is poorly represented and the observed climate of specific sites is not accurately reproduced (Coll et al. 2005, 
Engen-Skaugen 2007, Beldring et al. 2008). Consequently, the approach explored here used locallyresolved temperature lapse rate models (LRMs) variably integrated with temperature change outputs from an RCM and observed station data. Working on the basis that seasonal temperature regimes are a fundamental control on present altitudinal zones in maritime uplands, the LRMs were used to infer future shifts in the altitudinal bands associated with the present vegetation zones of the eastern Scottish Highlands based on shifts in key seasonal isotherms. Given the bio-climatic controls associated with the more continentally influenced eastern hills, for consistency we applied the approach for locations with similar climatic characteristics within our study region (Fig. 1a).

\section{MATERIALS AND METHODS}

\subsection{Study sites and delineation of vegetation zones}

The choice of climatological stations was constrained by the need to use valley stations with a sufficiently complete record and those with a reasonable proximity to the limited number of upland automatic weather station records available. This approach of using a single lower level station in conjunction with an upland station has been used extensively (see for example Harding 1978, Pages \& Miro 2010). Situated at $283 \mathrm{~m}$ in the Grampian Mountains of the eastern Highlands, the location of the Balmoral United Kingdom Meteorological Office (UKMO) station allows comparison with station records for a number of upland sites (Fig. 1b). This proximity to observed upland records, and the relatively low disparity between the Balmoral station elevation and that of the corresponding RCM grid cell allows for method evaluation. The stations are also located within some of the region's highest mountains, and are coincident with a number of designated sites of high conservation value in the surrounding area. This proximity to mountains with vegetation zones spanning elevation ranges typical of the eastern Highlands provides further scope for exploring the results. However, some interpretive judgements had to be applied in relation to delineating altitudinal zones, an issue explored further in Section 2.5.

\subsection{Climate data}

Daily temperature data for mean maxima $\left(\mathrm{T}_{\max }\right)$ and minima $\left(\mathrm{T}_{\min }\right)$ for Balmoral were obtained from the British Atmospheric Data Centre (BADC) database. Although the station was identified as having a largely intact record spanning the 1961-1990 baseline (BL)

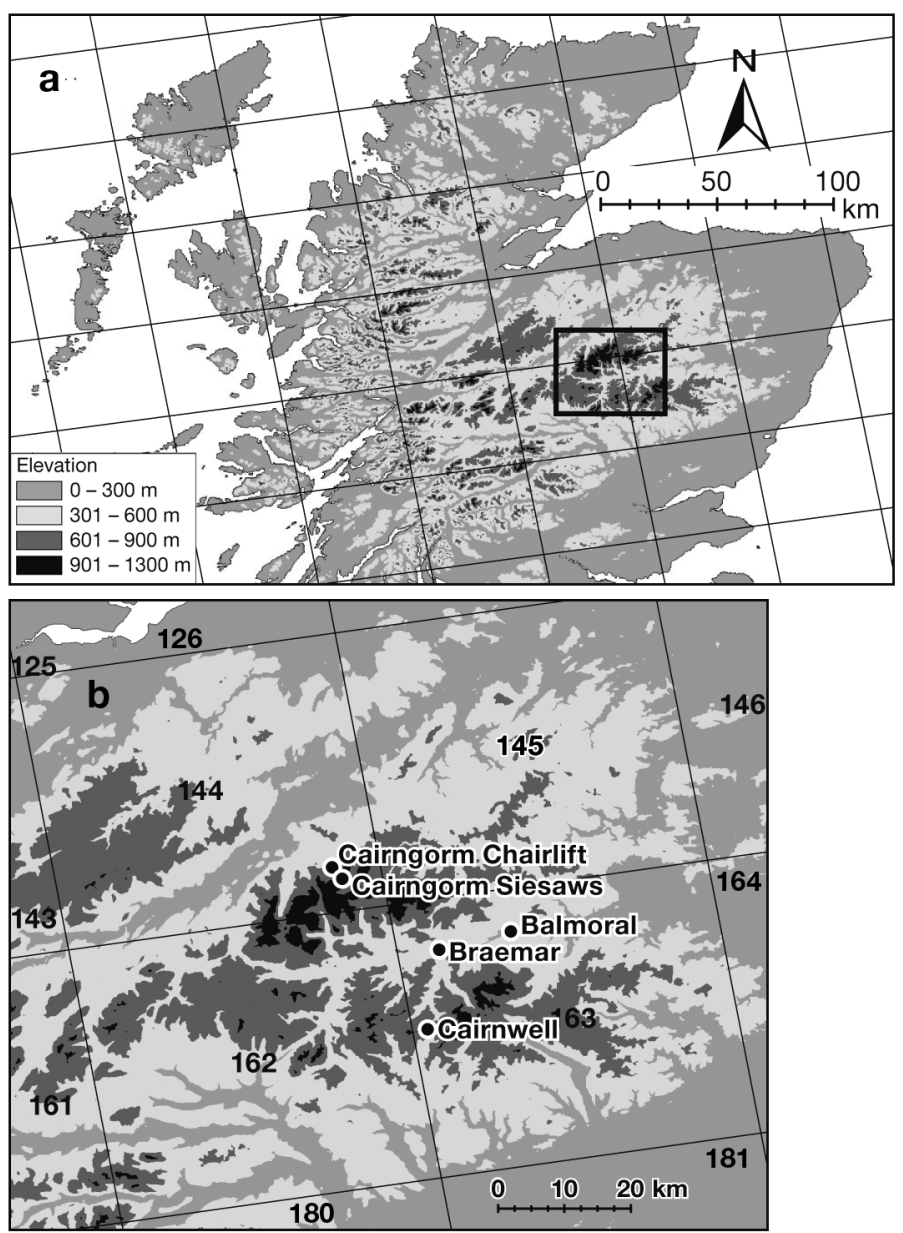

Fig. 1. (a) Northern Scotland overlain on a high-resolution digital elevation model (DEM). The elevation zones referred to in the text are shaded to indicate their extent, and the HadRM3H grid cells $(50 \times 50 \mathrm{~km})$ are overlain. Black rectangle: study region. (b) Study region in more detail. Dots: stations ; bold numbers: HadRM3H grid square codes

period, a number of quality control procedures were also applied to check for missing values. Thus e.g. for each year, files were scrutinised for the removal of default-999 missing value entries to avoid these skewing any subsequently derived mean values. These checks identified a small range of 2 to 4 missing daily values of $\mathrm{T}_{\max }$ and $\mathrm{T}_{\min }$ across the 1983-1990 daily records requiring backfilling by use of the adjacent daily mean values. Using a $30 \mathrm{yr}$ period for the baseline is also convenient since by encompassing natural variability, this averaging period effectively captures and smoothes out noise for use in an impact application (Carter et al. 1999). Following the data quality control procedures, annual and seasonal $\mathrm{T}_{\max }$ and $\mathrm{T}_{\min } \mathrm{BL}$ values were derived from the station record. Seasonal means were derived by climatological convention (e.g. Murphy et al. 2009), hence for winter the preceding 
year's December values were added to the January and February values.

Available upland climate data are limited for the Highlands, and no upland station has an intact record for the full BL period. However, a BADC search identified 3 candidate stations spanning a range of elevations, and with instrumental records of variable lengths (Table 1). Regional lapse rate values (LRVs) were obtained from the differences in seasonal mean values between those of the Balmoral station values and those of the highest station-Cairngorm Siesaws at $1245 \mathrm{~m}$ - and converted to ${ }^{\circ} \mathrm{C} \mathrm{km}^{-1}$ (Table 2). Simple deductive LRMs were derived based on the observed seasonal differences of temperature between the valley and upland records. These were applied to the observed $\mathrm{BL}\left(\mathrm{BL}_{\mathrm{Obs}}\right)$ for Balmoral at $10 \mathrm{~m}$ increments to enable the projection of changes with altitude. The LRMs were also applied to the Hadley Centre RCM (HadRM3H) BL simulated data $\left(\mathrm{BL}_{\mathrm{Sim}}\right.$ ) from the corresponding $50 \mathrm{~km}$ grid cell (ID 163, $339 \mathrm{~m}$ ) and these projected at the same $10 \mathrm{~m}$ increment. For comparison with work elsewhere, the LRVs $\left({ }^{\circ} \mathrm{C}\right.$ per $\left.10 \mathrm{~m}\right)$ used were compared with seasonal values (Table 2 ) derived from the recommended monthly lapse rates suggested by Blandford et al. (2008).

\subsection{Linear regression estimates of temperature with altitude}

Ordinary least squares (OLS) regression was applied to the $10 \mathrm{~m}$ LRM-derived values using altitude as a predictor for temperature on the basis that the SEs of this estimate of temperature with altitude would provide estimated confidence limits for the projected seasonal changes for the scenarios used. The OLS regressions were undertaken for all seasonal $T_{\max }$ and $\mathrm{T}_{\min } \mathrm{BL}$ values for both the $\mathrm{BL}_{\mathrm{Obs}}$ and $\mathrm{BL}_{\mathrm{Sim}}$ data. Arithmetic seasonal means $\left(\mathrm{T}_{\text {mean }}\right)$ were obtained from both $\mathrm{BL}_{\mathrm{Obs}}$ and $\mathrm{BL}_{\mathrm{Sim}}$ maxima and minima, and the OLS regressions repeated for the seasonal $\mathrm{T}_{\text {mean }}$ values. The fitted OLS models were checked for heteroscedasticity, and the standard residuals versus the fitted quantile-quantile (QQ) plot, Cook's distances and scale-location and residuals leverage plots were scrutinised in the $\mathrm{R}$ statistical computing environment to check that the regression assumptions had not been violated (Crawley 2007). Only the model summaries for the $\mathrm{BL}_{\mathrm{Obs}}$ OLS-derived values are provided in Table 3 , as these are the values on which the projected future changes are based.
Table 1. Upland stations and data record summary. Elevation: Cairngorm Chairlift: 663 m; Cairnwell: 933 m; Cairngorm Siesaws: $1245 \mathrm{~m}$

\begin{tabular}{|ll|}
\hline Station & Period (no. years) \\
\hline Winter & \\
Cairngorm Chairlift & $1982-1998(17)$ \\
Cairnwell & $1996-1999(4)$ \\
Cairngorm Siesaws & $1993-1999(7)$ \\
& \\
Other seasons and annual & $1981-1998(18)$ \\
Cairngorm Chairlift & $1995-1999(5)$ \\
Cairnwell & $1992-1999(8)$ \\
Cairngorm Siesaws & \\
\hline
\end{tabular}

\subsection{Climate change data, data matching and scenario selection}

The HadRM3H integrations were used to produce the United Kingdom Climate Impacts Programme 2002 (UKCIP02) climate change scenarios for the UK (Hulme et al. 2002), although these have now been superseded by the new UKCP09 scenarios (Murphy et al. 2009). Boundary conditions for HadRM3H are derived from the global atmosphere model, HadAM3H (Gordon et al. 2000, Pope et al. 2000), which is of intermediate scale between the coarser-resolution HadCM3 and the RCM. The double-nesting approach used in the model improves the quality of the simulated European climate and allows the UKCIP02 scenarios to present information with a higher spatial resolution of $50 \mathrm{~km}$ (Fig. 1) rather than 250 to $300 \mathrm{~km}$ (Hulme et al. 2002, Fowler et al. 2005).

$\mathrm{BL}_{\mathrm{Sim}}$ values of mean annual and seasonal $\mathrm{T}_{\max }$ and $\mathrm{T}_{\min }$ for the 1961-1990 baseline for the HadRM3H $50 \mathrm{~km}$ grid corresponding to the station location were obtained from the UKCIP02 database, and the differences between the station and the corresponding HadRM3H $50 \mathrm{~km}$ grid cell elevation $(\Delta \mathrm{m})$ were recorded. Compared to Balmoral at $283 \mathrm{~m}$, the

Table 2. Seasonal temperature lapse rate values $\left(\mathrm{km}^{-1}\right)$ derived from Balmoral and Cairngorm Siesaws paired station values, and seasonal temperature lapse rate values (per $10 \mathrm{~m}$ ) projected in models, and comparison with other recorded values (BLF: data from Blandford et al. 2008). Values in brackets: differences. $\mathrm{T}_{\text {max }}$ : maximum temperature; $\mathrm{T}_{\min }$ : minimum temperature; $\mathrm{LRM}$ : lapse rate model

\begin{tabular}{|c|c|c|c|c|c|c|}
\hline \multirow[t]{2}{*}{ Season } & \multicolumn{2}{|c|}{ Lapse rate $\left({ }^{\circ} \mathrm{C} \mathrm{km}^{-1}\right)$} & \multicolumn{4}{|c|}{ Lapse rate $\left({ }^{\circ} \mathrm{C} 10 \mathrm{~m}^{-1}\right)$} \\
\hline & $\mathrm{T}_{\max }$ & $\mathrm{T}_{\min }$ & $\begin{array}{c}\text { LRM } \\
T_{\max }\end{array}$ & $\begin{array}{l}\text { LRM } \\
\mathrm{T}_{\min }\end{array}$ & $\begin{array}{l}\text { BLF } \\
T_{\max }\end{array}$ & $\begin{array}{l}\text { BLF } \\
\mathrm{T}_{\min }\end{array}$ \\
\hline Spring & 9.46 & 3.27 & 0.09 & 0.03 & $0.06(0.03)$ & $0.03(0.00)$ \\
\hline Summer & 11.49 & 4.27 & 0.11 & 0.04 & $0.07(0.04)$ & $0.01(0.03)$ \\
\hline Autumn & 8.64 & 3.59 & 0.09 & 0.04 & $0.06(0.03)$ & $0.01(0.03)$ \\
\hline Winter & 6.96 & 3.53 & 0.07 & 0.04 & $0.05(0.02)$ & $0.02(0.02)$ \\
\hline
\end{tabular}


Table 3. Summary of ordinary least squares (OLS) regression coefficients for Balmoral station seasonal value projections. $\mathrm{p}(>|t|)<2 \times 10^{-16}$ (highly significantat or near 0 ) for all OLS fitted values. $\mathrm{T}_{\max }$ : maximum temperature; $\mathrm{T}_{\min }$ : minimum temperature

\begin{tabular}{|c|c|c|c|c|c|}
\hline \multicolumn{2}{|c|}{$\begin{array}{l}\text { Seasonal } \\
\text { temperature }\end{array}$} & $\begin{array}{c}\text { OLS coefficient } \\
\text { term }\end{array}$ & Estimate & $\mathrm{SE}$ & $t$ \\
\hline \multirow[t]{2}{*}{ Spring } & $\mathrm{T}_{\max }$ & $\begin{array}{l}\text { Intercept } \\
\text { Elev }\end{array}$ & $\begin{array}{c}1.183 \times 10^{1} \\
-8.889 \times 10^{-3}\end{array}$ & $\begin{array}{l}6.984 \times 10^{-3} \\
8.289 \times 10^{-6}\end{array}$ & $\begin{array}{r}1694 \\
-1072\end{array}$ \\
\hline & $\mathrm{T}_{\min }$ & $\begin{array}{l}\text { Intercept } \\
\text { Elev }\end{array}$ & $\begin{array}{c}1.790 \\
-2.963 \times 10^{-3}\end{array}$ & $\begin{array}{l}2.328 \times 10^{-3} \\
2.763 \times 10^{-6}\end{array}$ & $\begin{array}{r}768.9 \\
-1072.4\end{array}$ \\
\hline \multirow[t]{2}{*}{ Summer } & $\mathrm{T}_{\max }$ & $\begin{array}{l}\text { Intercept } \\
\text { Elev }\end{array}$ & $\begin{array}{c}1.990 \times 10^{1} \\
-1.086 \times 10^{-2}\end{array}$ & $\begin{array}{l}8.536 \times 10^{-3} \\
1.013 \times 10^{-5}\end{array}$ & $\begin{array}{r}2331 \\
-1072\end{array}$ \\
\hline & $\mathrm{T}_{\min }$ & $\begin{array}{l}\text { Intercept } \\
\text { Elev }\end{array}$ & $\begin{array}{c}8.293 \\
-3.950 \times 10^{-3}\end{array}$ & $\begin{array}{l}3.104 \times 10^{-3} \\
3.684 \times 10^{-6}\end{array}$ & $\begin{array}{r}2672 \\
-1072\end{array}$ \\
\hline \multirow[t]{2}{*}{ Autumn } & $\mathrm{T}_{\max }$ & $\begin{array}{l}\text { Intercept } \\
\text { Elev }\end{array}$ & $\begin{array}{c}1.324 \times 10^{1} \\
-8.889 \times 10^{-3}\end{array}$ & $\begin{array}{l}6.984 \times 10^{-3} \\
8.289 \times 10^{-6}\end{array}$ & $\begin{array}{r}1896 \\
-1072\end{array}$ \\
\hline & $\mathrm{T}_{\min }$ & $\begin{array}{l}\text { Intercept } \\
\text { Elev }\end{array}$ & $\begin{array}{c}4.253 \\
-3.950 \times 10^{-3}\end{array}$ & $\begin{array}{l}3.104 \times 10^{-3} \\
3.684 \times 10^{-6}\end{array}$ & $\begin{array}{r}1370 \\
-1072\end{array}$ \\
\hline \multirow[t]{2}{*}{ Winter } & $\mathrm{T}_{\max }$ & $\begin{array}{l}\text { Intercept } \\
\text { Elev }\end{array}$ & $\begin{array}{c}6.323 \\
-6.913 \times 10^{-3}\end{array}$ & $\begin{array}{l}5.432 \times 10^{-3} \\
6.447 \times 10^{-6}\end{array}$ & $\begin{array}{r}1164 \\
-1072\end{array}$ \\
\hline & $\mathrm{T}_{\min }$ & $\begin{array}{l}\text { Intercept } \\
\text { Elev }\end{array}$ & $\begin{array}{l}-9.069 \times 10^{-1} \\
-3.950 \times 10^{-3}\end{array}$ & $\begin{array}{l}3.104 \times 10^{-3} \\
3.684 \times 10^{-6}\end{array}$ & $\begin{array}{r}-292.2 \\
-1072.4\end{array}$ \\
\hline
\end{tabular}

nal life zones found in continental Europe, and the potential upper extent of the tree line is masked due to grazing pressure (Thompson et al. 2005, Fischlin et al. 2007).

For the purposes of utility, in the eastern Highlands $600 \mathrm{~m}$ is interpreted as being the upper limit of the forest zone, $900 \mathrm{~m}$ as the upper limit of the sub-alpine zone and the lower limit of the low-alpine zone, and $1200 \mathrm{~m}$ as the lower limit of the middle-alpine zone. Ratcliffe \& Thompson (1988) and Ratcliffe (1977) preferred to describe the different vegetation zones on mountains as montane when referring to Britain. According to them, the sub-montane zone includes all vegetation derived from forest above the limits of enclosed farmland, an interpretation which also extends to other UK upland regions (Orr et al. 2008).

HadRM3H Grid 163 elevation is $339 \mathrm{~m}(\Delta 56 \mathrm{~m})$. To eliminate any bias due to lapse rate adjustment, the HadRM3H values were fitted to the LRMs from $340 \mathrm{~m}$ to correspond with the grid cell elevation, and to allow a direct inter-comparison of the simulated and observed values projected through the LRMs and subsequently fitted to the OLS regression models

Prior to selecting the HadRM3H temperature change outputs $\left(\Delta \mathrm{T},{ }^{\circ} \mathrm{C}\right)$ used for running the climate change signal through the BL LRMs, some scenario selection criteria were applied. Although scenarios across a number of future time slices represent a range of possible development pathways and encompass different levels of uncertainty, results for the 2050s Low and 2050s High scenario data are presented. These are used on the basis that the sources and range of uncertainties cascade for later century projections, while the absence of a concerted mitigation response, allied to the thermal inertia of the climate system and the effective lifetime of some greenhouse gases may contribute to realising the magnitude of warming projected for the 2050s.

\subsection{Delineating vegetation zones}

Any classification scheme or delineation point can only be indicative, since the landscapes of the Highlands have been subject to substantial anthropogenic modification as a result of e.g. deforestation, burning and grazing management (Orr et al. 2008). As a result, landscapes here lack the typical sequence of altitudi-
However, here we applied a modified interpretation of the (European) continental terminology recommended by Horsefield \& Thompson (1996), i.e. the alpine zone has been sub-divided to accommodate the continental nomenclature, and the same approximate elevation boundaries were applied. However, delineations are only approximate because vegetation zones are at lower elevations in the far north and west of the Highlands, associated with the effect of relatively steep lapse rates superimposed on latitudinal controls.

\section{RESULTS}

\subsection{LRM validation using Balmoral station values}

The OLS fitted range of seasonal values for $\mathrm{T}_{\max }$ and $\mathrm{T}_{\text {min }}$ derived from the $10 \mathrm{~m}$ values obtained via the LRMs were projected through the observed seasonal instrumental upland records (IURs) to provide an assessment of performance (Fig. 2, Table 4). Overall, there was a good agreement of fit around the observed station values across all seasons for the OLS regression fitted values of $\mathrm{T}_{\max }$ and $\mathrm{T}_{\min }$. In general, the $\mathrm{BL}_{\mathrm{Obs}}$ projected values fit more closely to the station points than the $\mathrm{BL}_{\mathrm{Sim}}$ projections (Table 5); given that the LRVs used to construct the models were derived from the station data, this is not surprising. However, the fit for the $\mathrm{BL}_{\mathrm{Obs}}$ values was generally better for $\mathrm{T}_{\max }$, with some cold bias evident for $\mathrm{T}_{\min }$ in autumn and winter with respect to the station values. 
By comparison, for the projected $\mathrm{BL}_{\text {Sim }}$ values there was less overall agreement with the station values. For example, there was a cold bias for the summer and autumn $\mathrm{T}_{\max }$ projected values, whereas for the spring and winter $\mathrm{T}_{\max }$ projections, there was a warm bias compared to the station and $\mathrm{BL}_{\mathrm{Obs}}$ projected values. There was also an overall warm bias for the projected $\mathrm{BL}_{\text {Sim }}$ values of $\mathrm{T}_{\text {min, }}$ most notably for spring and winter. As indicated above, the relatively close correspondence of the Balmoral station and HadRM3H grid

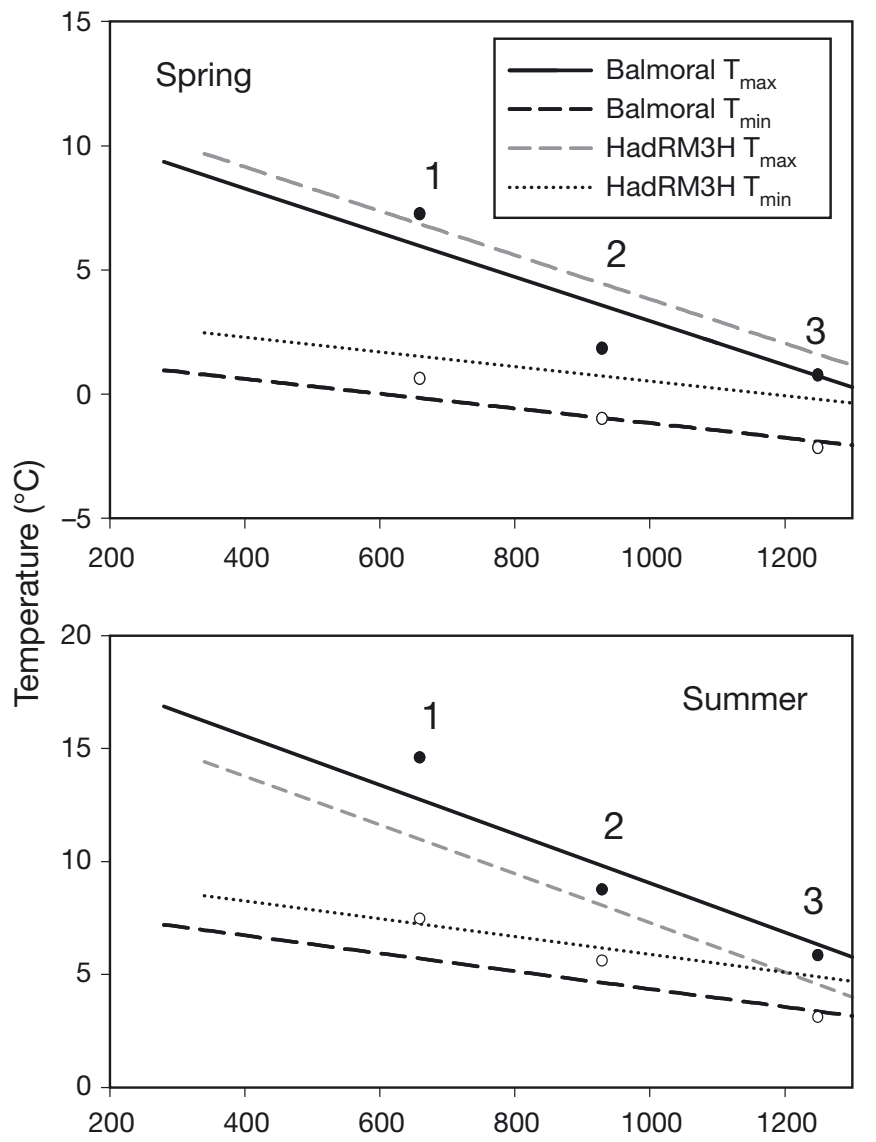

elevations allowed for a relatively unambiguous interpretation of HadRM3H seasonal temperature simulation performance, and this together with upland record availability determined the study location. With reference to the station values, HadRM3H underestimated summer and autumn mean maxima, while simulated spring and winter maxima were slightly higher. The differences in summer maxima were quite marked and suggest that the parameterisations within HadRM3H may not be capturing local valley heating effects in the
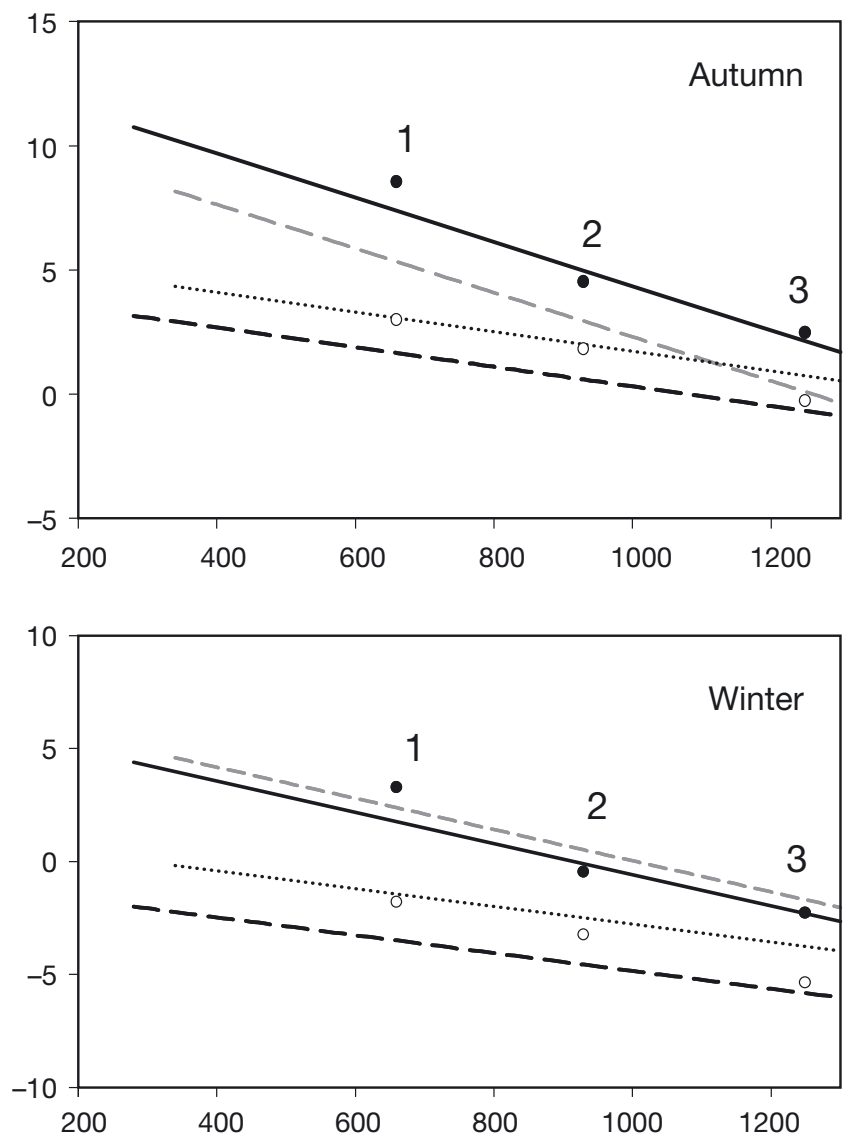

Altitude (m)

Fig. 2. Balmoral baseline observed (BL $\mathrm{Obs}_{\mathrm{O}}$ ) and HadRM3H grid ID 163 baseline simulated (BL $\mathrm{B}_{\mathrm{Sim}}$ ) mean seasonal maximum and minimum temperature $\left(\mathrm{T}_{\max }\right.$ and $\left.\mathrm{T}_{\min }\right)$ lapse rate adjusted and projected. Closed circles: upland station $\mathrm{T}_{\max }$, open circles: $\mathrm{T}_{\min }$. 1: Cairngorm chairlift, 2: Cairnwell, 3: Cairngorm Siesaws

Table 4. Lapse rate model projected (nearest $10 \mathrm{~m}$ ) seasonal Balmoral observed baseline $\left(\mathrm{BL}_{\mathrm{Obs}}\right)$ values of maximum and minimum temperature $\left(\mathrm{T}_{\max }\right.$ and $\left.\mathrm{T}_{\min }\right)$ compared to station values. Model projections in round brackets

\begin{tabular}{|c|c|c|c|c|c|c|c|c|}
\hline \multirow[t]{2}{*}{ Station [elevation, m] } & \multicolumn{2}{|c|}{ Spring } & \multicolumn{2}{|c|}{$\longrightarrow$ Summer } & \multicolumn{2}{|c|}{-Autumn } & \multicolumn{2}{|c|}{ Winter } \\
\hline & $\mathrm{T}_{\max }$ & $\mathrm{T}_{\min }$ & $\mathrm{T}_{\max }$ & $\mathrm{T}_{\min }$ & $\mathrm{T}_{\max }$ & $\mathrm{T}_{\min }$ & $\mathrm{T}_{\max }$ & $\mathrm{T}_{\min }$ \\
\hline Cairr & $7.22(5.95)$ & $0.59(-0.17)$ & 14.57 (12.71) & 7.43 & $.36)$ & 2.9 & $.75)$ & -1 \\
\hline Cairnwell [933] & $1.80(3.52)$ & $-1.02(-0.98)$ & $8.72(9.74)$ & $5.58(4.60)$ & 4.49 (4.93) & $1.78(0.56)$ & $-0.50(-0.14)$ & $-3.28(-4.6)$ \\
\hline Cairngorm Siesaws [1245] & $0.72(0.73)$ & $-2.19(-1.91)$ & $5.81(6.33)$ & $3.08(3.36)$ & $2.44(2.14)$ & $-0.30(-0.68)$ & $-2.31(-2.31)$ & $-5.41(-5.84)$ \\
\hline
\end{tabular}


eastern Highlands. By contrast, and with reference to the station values, HadRM3H overestimated mean $\mathrm{T}_{\text {min }}$ across the full seasonal range. The marked differences for winter and spring $\mathrm{T}_{\min }$ indicate that the HadRM3H parameterisations did not capture the frost hollow effects associated with this site. The assumption in the modelling approach that temperature is linear with altitude captures these systematic differences between the $\mathrm{BL}_{\mathrm{Obs}}$ and $\mathrm{BL}_{\mathrm{Sim}}$ values, and projects them through the LRMs.

\subsection{Projecting seasonal isotherm shifts using the models}

For these projections, the approximate elevations associated with upland vegetation zones in the eastern Highlands detailed above were applied. The seasonal LRVs for both $\mathrm{T}_{\max }$ and $\mathrm{T}_{\min }$ were used in the OLS regression models with altitude as a predictor, and the $\mathrm{T}_{\max }$ and $\mathrm{T}_{\min }$ isotherm values associated with the upper limit of each vegetation zone derived from the projected Balmoral $\mathrm{BL}_{\text {Obs }}$ values (Table 6).

The $\mathrm{BL}_{\mathrm{Obs}}$ values for Balmoral were adjusted using the HadRM3H grid simulated temperature outputs

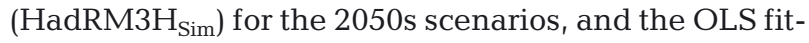
ted values used to project these changes with altitude at $10 \mathrm{~m}$ intervals. The new mean isotherm $\left(\mathrm{M}_{\mathrm{i}}\right)$ location for the upper limit of each vegetation zone was recalculated, and the new elevation of $\mathrm{M}_{\mathrm{i}}$ associated with $\mathrm{T}_{\text {max }}$ and $\mathrm{T}_{\text {min }}$ for the climate change projected changes was recorded together with the vertical migration involved (Table 7). For consistency of interpretation, the derived lower $10 \mathrm{~m}$ band was interpreted as the future location of the $\mathrm{M}_{\mathrm{i}}$ values for each zone; for pragmatic purposes, no projections were extended beyond $1400 \mathrm{~m}$ as this elevation is just above the highest hills. Future isotherm shifts for each scenario at Balmoral are summarised in Fig. 3, alongside some exaggerated error bars. Since it is the suite of seasonal changes which will drive prospective changes in the uplands, the full range of changes for $T_{\max }$ and $T_{\min }$ are presented and the ecological implications of these are explored further in Section 4.3.

\subsection{Climate change projections applied to the Balmoral data}

For both scenarios, the greatest uphill shifts were for $\mathrm{T}_{\min }$ isotherm values across all seasons, but most notably for autumn and spring. The HadRM3 $\mathrm{H}_{\text {Sim }}$ values projected autumn shifts of $330 \mathrm{~m}$ upslope for the $\mathrm{M}_{\mathrm{i}}$ values associated with the forest-sub-alpine transition zone, and a corresponding shift for the sub-alpinelow-alpine transition zone isotherm for the 2050s Low scenario. For the 2050s High scenario, the uphill migration of the autumn $T_{\min } M_{i}$ value for the forestsub-alpine transition was $530 \mathrm{~m}$, while the sub-alpinelow-alpine transition zone isotherm was projected as being above the summits. Compared to shifts in $\mathrm{T}_{\text {min }}$, those for $\mathrm{T}_{\max }$ were smaller, with HadRM3H $\mathrm{H}_{\text {Sim }}$ projecting a 120 to $160 \mathrm{~m}$ shift in range for each zone across the seasons for the 2050s Low scenario, although $\mathrm{M}_{\mathrm{i}}$ shifts for the $\mathrm{T}_{\max }$ isotherms associated with the transition zones were more substantial for the 2050s High scenario. The vertical migration of the spring $\mathrm{T}_{\min }$ values was also substantial for both scenarios and across

Table 5. Lapse rate model projected (nearest $10 \mathrm{~m}$ ) seasonal HadRM3H BL $\mathrm{L}_{\text {sim }}$ values of maximum and minimum temperature ( $\mathrm{T}_{\max }$ and $\mathrm{T}_{\min }$ ) compared to station values. Model projected values in round brackets

\begin{tabular}{|c|c|c|c|c|c|c|c|c|}
\hline \multirow[t]{2}{*}{ Station [elevation, m] } & \multicolumn{2}{|c|}{ - Spring } & \multicolumn{2}{|c|}{ - Summer } & \multicolumn{2}{|c|}{-Autumn } & \multicolumn{2}{|c|}{ - Winter } \\
\hline & $\mathrm{T}_{\max }$ & $\mathrm{T}_{\min }$ & $\mathrm{T}_{\max }$ & $\mathrm{T}_{\min }$ & $\mathrm{T}_{\max }$ & $\mathrm{T}_{\min }$ & $\mathrm{T}_{\max }$ & $\mathrm{T}_{\min }$ \\
\hline Cairngorm Chairlift [663] & $7.22(6.82)$ & $0.59(1.52)$ & $14.57(10.93)$ & $7.43(7.21)$ & $8.51(5.31)$ & $2.96(3.06)$ & $3.25(2.36)$ & $-1.83(-1.45)$ \\
\hline Cairnwell [933] & $1.80(4.39)$ & $-1.02(0.71)$ & $8.72(7.96)$ & $5.58(6.13)$ & $4.49(2.88)$ & $1.78(1.98)$ & $-0.50(0.47)$ & $-3.28(-2.53)$ \\
\hline Cairngorm Siesaws [1245] & $0.72(1.60)$ & $-2.19(-0.22)$ & $5.81(4.55)$ & $3.08(4.89)$ & $2.44(0.09)$ & $-0.30(0.74)$ & $-2.31(-1.7)$ & $-5.41(-3.77)$ \\
\hline
\end{tabular}

Table 6. Summary of baseline projected seasonal 1961-1990 isotherm values associated with vegetation zones derived from ordinary least squares regression-projected Balmoral values

\begin{tabular}{|c|c|c|c|c|c|c|c|c|c|c|c|c|}
\hline \multirow{2}{*}{$\begin{array}{l}\text { Vegetation transition } \\
\text { zone (elevation, m) }\end{array}$} & \multicolumn{3}{|c|}{ Spring } & \multicolumn{3}{|c|}{ Summer } & \multicolumn{3}{|c|}{-Autumn } & \multicolumn{3}{|c|}{-Winter } \\
\hline & $\mathrm{T}_{\max }$ & $\mathrm{T}_{\min }$ & $\mathrm{T}_{\text {mean }}$ & $\mathrm{T}_{\max }$ & $\mathrm{T}_{\min }$ & $\mathrm{T}_{\text {mean }}$ & $\mathrm{T}_{\max }$ & $\mathrm{T}_{\min }$ & $\mathrm{T}_{\text {mean }}$ & $\mathrm{T}_{\max }$ & $\mathrm{T}_{\min }$ & $\mathrm{T}_{\text {mean }}$ \\
\hline Forest - Sub-alpine (600) & 6.50 & 0.01 & 3.25 & 13.38 & 5.92 & 9.65 & 7.91 & 1.88 & 4.89 & 2.18 & -3.28 & -0.55 \\
\hline Sub - Low-alpine (900) & 3.83 & -0.88 & 1.48 & 10.12 & 4.74 & 7.43 & 5.24 & 0.70 & 2.97 & 0.10 & -4.46 & -2.18 \\
\hline Low - Middle-alpine (1200) & 1.16 & -1.77 & -0.30 & 6.86 & 3.55 & 5.21 & 2.57 & -0.49 & 1.04 & -1.97 & -5.65 & -3.81 \\
\hline
\end{tabular}


Table 7. Summary of new elevations (m) associated with vegetation zone isotherms for 2050s scenarios based on the HadRM3H $\mathrm{H}_{\text {Sim }}$ projections via the lapse rate models (LRMs). Brackets: projected shift $(\Delta \mathrm{m})$ compared to the 1961-1990 isotherm location estimate for each zone. AS: above present summit levels

\begin{tabular}{|c|c|c|c|c|c|c|c|c|}
\hline \multirow{2}{*}{$\begin{array}{l}\text { 1961-1990 vegetation } \\
\text { transition zone } \\
\text { Scenario }\end{array}$} & \multicolumn{2}{|c|}{ Spring -} & \multicolumn{2}{|c|}{ Summer } & \multicolumn{2}{|c|}{ Autumn } & \multicolumn{2}{|c|}{ Winter } \\
\hline & $\mathrm{T}_{\max }$ & $\mathrm{T}_{\min }$ & $\mathrm{T}_{\max }$ & $\mathrm{T}_{\min }$ & $\mathrm{T}_{\max }$ & $\mathrm{T}_{\min }$ & $\mathrm{T}_{\max }$ & $\mathrm{T}_{\min }$ \\
\hline \multicolumn{9}{|l|}{ Forest - Low-alpine } \\
\hline 2050s low & $720(120)$ & $950(350)$ & $720(120)$ & $900(300)$ & $750(150)$ & $930(330)$ & $730(130)$ & $840(240)$ \\
\hline 2050s high & $800(200)$ & $1170(570)$ & $810(210)$ & $1080(480)$ & $850(250)$ & $1130(530)$ & $810(210)$ & $980(380)$ \\
\hline \multicolumn{9}{|l|}{ Sub - Low-alpine } \\
\hline 2050 s low & $1030(130)$ & $1260(360)$ & 1030 & $1200(300)$ & $1060(160)$ & $1230(330)$ & 1040 & $1140(240)$ \\
\hline 2050s high & $1110(210)$ & AS (550) & $1120(220)$ & $\mathrm{AS}(\Delta 480)$ & $1160(260)$ & AS (520) & $1120(220)$ & $1290(390)$ \\
\hline \multicolumn{9}{|l|}{ Low - Middle-alpine } \\
\hline 2050s low & AS & AS & AS & AS & $\mathrm{AS}$ & AS & $\mathrm{AS}$ & AS \\
\hline 2050s high & AS & AS & AS & AS & AS & AS & AS & AS \\
\hline
\end{tabular}

the zones. In terms of ecological impacts, such changes, if realised, could be profound, both in terms of the implications for snow lie and the timing of biological activity in upland areas more generally. A notable feature across both scenarios was the complete loss (at least in thermal terms) of the entire middle-alpine zone, together with most of the low-middle-alpine transition zone.

\section{DISCUSSION}

\subsection{Braemar station and UKMO regionally averaged monthly data comparison}

Given the apparent pattern of $\mathrm{BL}_{\mathrm{Sim}}$ not capturing seasonal local valley effects, UKMO data for the nearby Braemar station were used to examine differences at a monthly rather than seasonal resolution. At $339 \mathrm{~m}$, Braemar is at the same elevation as the HadRM3H grid 163 (339 m) and allowed direct comparison with the RCM-simulated monthly outputs for a station also subject to frost hollow effects. Mean monthly observed $\mathrm{T}_{\max }$ and $\mathrm{T}_{\min }$ values were also obtained from the UKMO regionally averaged data and were plotted alongside the HadRM3H grid-simulated values (Fig. 4).

Fig. 4 highlights that compared to the Braemar observed monthly $\mathrm{T}_{\max }$ values, the HadRM3H grid consistently underestimated mean $\mathrm{T}_{\max }$ for most of the spring, summer and autumn months, but slightly overestimated mean $\mathrm{T}_{\max }$ for the winter months. The greatest cold bias for model simulated $\mathrm{T}_{\max }$ was associated with the summer $\left(-2.41^{\circ} \mathrm{C}\right)$ and autumn $\left(-2.56^{\circ} \mathrm{C}\right)$ months, suggesting that the RCM outputs did not cap- ture localised valley heating effects in these seasons. When compared with the UKMO regionally averaged data, these biases were not so pronounced and the RCM-simulated values were closer to the observed monthly pattern; unfortunately, however, no mean elevation data in relation to the regionally averaged data were provided by UKMO.

By contrast, for the simulation of $\mathrm{T}_{\min }$, compared to the Braemar data there was a more consistent warm bias in the RCM-simulated values, which is most marked in the late autumn $\left(+1.19^{\circ} \mathrm{C}\right)$ and early spring $\left(+1.52^{\circ} \mathrm{C}\right)$ months. However, when compared with the UKMO regionally averaged data, these biases were not so pronounced, and the RCM-simulated values were again closer to the observed data. Firm conclusions cannot be drawn due to the different spatial scales of the UKMO regionally averaged data and the HadRM3H grid, and the lack of mean elevation data for the former. Nonetheless, when comparing station points subject to known and marked seasonal contrasts controlled largely by local site characteristics, the relatively coarse resolution of the HadRM3H grid failed to capture important seasonal details of local climate.

\subsection{Lapse rate models}

An environmental lapse rate of $\sim 0.6^{\circ} \mathrm{C}$ per $100 \mathrm{~m}$ is commonly used to estimate the air temperature at unmeasured locations from available weather stations (Blandford et al. 2008). While it is a simple method that effectively captures the general temperature-elevation trend, it may not effectively describe localised temperature and elevation trends, and hence offers a poor description of the spatial temperature structure (Lund- 

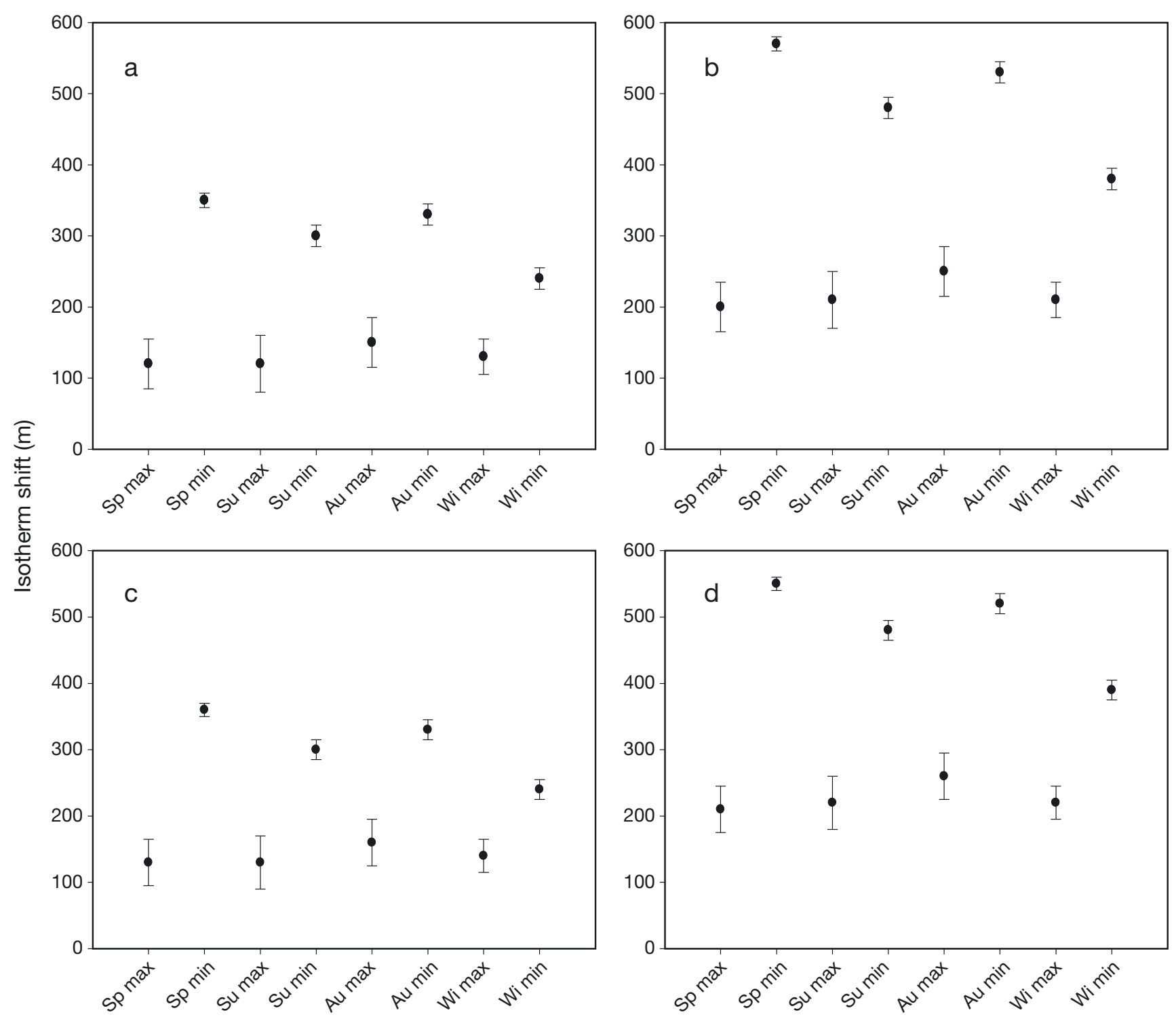

Seasonal value

Fig. 3. Projected seasonal isotherm shifts relative to 1961-1990 for the two 2050s scenarios, (a,c) Low; (b,d) High. (a,b) ForestSub-alpine transition zone $(600 \mathrm{~m})$; $(\mathrm{c}, \mathrm{d})$ Sub-alpine-Low-alpine transition zone $(900 \mathrm{~m})$. Vertical scale of error bars is greatly exaggerated $(\times 500)$ to accommodate the scale mismatch in relation to the prospective isotherm shifts

quist \& Cayan 2007). Instead, lapse rates vary with factors such as latitude and topographic slope, and also have a significant seasonal trend (Rolland 2003). Consequently, there are numerous simplifying assumptions in treating the environmental lapse rate as spatially and temporally constant. While we attempted to deal with this here by applying locally derived mean seasonal fluctuations to the LRVs used, these still take no account of important and fluctuating sub-seasonal controls such as cloud cover, wind and snow cover, which account for local differences in daytime $\mathrm{T}_{\max }$ at upland sites (Pepin \& Seidel 2005). Late-lying snow at high elevations in spring is also an important control on lapse rates for upland areas in the Highlands, since it cools surface air and steepens local temperature gradients (McClatchey 1996). Other physical controls on temperature change such as the net radiation budget (Pepin \& Seidel 2005) were also excluded from the seasonal LRVs applied.

Similarly, the application of seasonally resolved values cannot take account of the variability introduced by the synoptic controls associated with certain frontal types and the variation these introduce. Air mass characteristics are an important control on lapse rates, with synoptic types comprised of westerly components showing the most rapid decrease of temperature with 

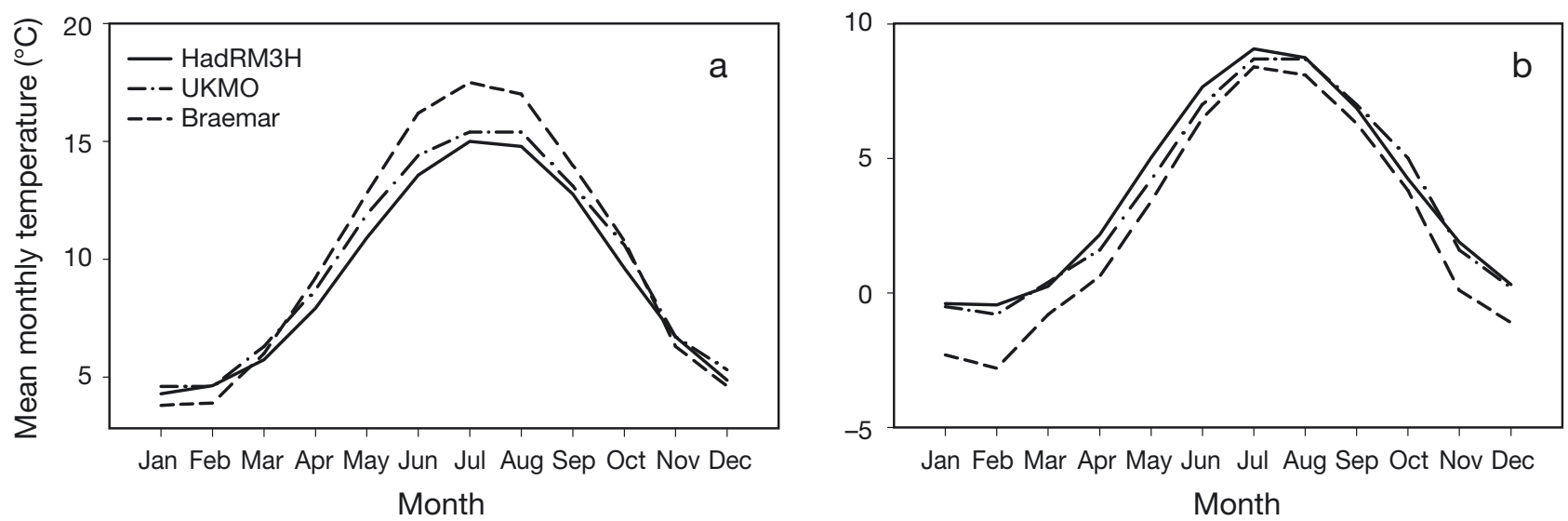

Fig. 4. Mean monthly (a) maximum and (b) minimum temperature ( $\mathrm{T}_{\max }$ and $\mathrm{T}_{\min }$, respectively) values over the 1961-1990 baseline period for Braemar station and HadRM3H grid cell 163 (simulated), and UKMO (regional average)

elevation (Pepin 2001). For the Cairngorms, steeper gradients have been reported for Polar or Arctic maritime air (Pm and Am) and Polar continental (Pc) air, and shallower rates associated with Tropical maritime (Tm) or returned Polar maritime air (rPm; McClatchey 1996). These steep temperature lapse rates are a particular feature of Pm air masses, especially in spring (Harding 1978, Harrison 1994, Pepin 1995). Lapse rates are also steeper when there is a strong altitudinal increase in cloud cover, decrease in sunshine duration or strong wind shear (Pepin 2001), with the fall in maximum temperature with height considerably more rapid than the fall in minimum temperature. Temperature gradients of -7.0 to $-10.0^{\circ} \mathrm{C} \mathrm{km}^{-1}$ have been recorded for the Cairngorms during the middle of the day (12:00-15:00 h GMT) when temperatures are highest (McClatchey 1996). There is also considerable seasonal variation, with the steepest lapse rates occurring in spring associated with the seasonal dominance of Pm air masses (McClatchey 1996).

Examination of the LRVs used (Table 2) indicated relatively steep values for $\mathrm{T}_{\max }$ and $\mathrm{T}_{\min }$ compared to values recorded elsewhere (Blandford et al. 2008), with the summer and autumn differences especially marked. However, Blandford et al. (2008) were working with data from a mountain basin in the continental interior, whereas in a maritime region where lapse rates are recognised to be steeper, differences should be expected. Despite the differences, the steeper rates recorded during the warmer months are consistent with other work (Harding 1978, Rolland 2003, Blandford et al. 2008). A comparison across European mountain regions also indicates that typical temperature gradients for the Highlands are steeper across the year (particularly for the east) compared to other areas, but with a marked reduction in the amplitude of monthly variation compared to other European mountain areas (Thompson et al. 2009). The differences also reinforce the point that the application of relationships across mountain areas is unwise even within mid-latitude regions due to the range of lapse rate differences recorded (Rolland 2003); moreover, these vary both between airflow types and spatially due to variation in the vertical temperature structure within airflow types (Pepin 2001). Therefore, and for similar reasons, i.e. the use of locally specific LRVs, the potential climate change shift projections reported here should be considered region specific.

These issues aside, wider uncertainties remain surrounding the use of scenario outputs from GCMs and RCMs, and these will be cascaded through the HadRM $3 \mathrm{H}_{\text {Sim }}$ projections, while some of the biases associated with the LRMs themselves are indicated. The general difficulties of obtaining representative temperature LRVs for use in landscape ecology and other applications in the absence of a high density monitoring network are well documented (e.g. Harlow et al. 2004, Lundquist \& Cayan 2007). Similarly, the cold air ponding associated with sites such as Balmoral which decouples surface climate from the free-atmosphere is known to be a strong influence on mountain climate in areas of concave topography (Pepin 2010). Consequently, the issue of accuracy when projecting from valley sites subject to local topographic effects is well documented; however, the use of the upland station records to validate the models here represents an attempt to counter this problem. Therefore, we suggest that our work represents an advance in terms of deriving locally relevant projections of temperature change with altitude; for example, Moen et al. (2004) did not apply such a range of LRVs in their approach. Similarly, the seasonal range of lapse rate adjustments applied here is wider than the adjustment applied to daily temperature outputs from an RCM to correct for altitude biases between RCM grids and station data by Engen-Skaugen (2007). 


\subsection{Modelled isotherm shifts and their ecological implications}

Aside from climate change uncertainties and the biases associated with the LRMs, ecosystem responses to relatively rapid changes in temperature remain poorly understood. Similarly, it is recognised that at finer scales, local topographic controls such as aspect and slope would cause microclimatic effects leading to considerable variation for any vegetation boundaries defined by altitude alone. Provided there is an accurate assessment of the lapse rate, applying Koppen's rule, for example, approximates the montane tree line to the $10^{\circ} \mathrm{C} \mathrm{T}_{\text {mean }}$ isotherm for the warmest month in the year (Koppen 1931). However, at continental scales there are indications that mean summer temperature correlates with tree-line position over large scales (Grace et al. 2002, Moen et al. 2004). Thus, while Fig. 4 shows a substantial altitudinal shift in mean summer $\mathrm{T}_{\max }$ and $\mathrm{T}_{\min }$ (and hence $\mathrm{T}_{\text {mean }}$ ), vegetation zones will not move in a direct linear response to temperature. In continental areas with a lapse rate of $0.6^{\circ} \mathrm{C}$ per $100 \mathrm{~m}$, a $1^{\circ} \mathrm{C}$ increase in temperature would be expected to elevate the tree line by $\sim 170 \mathrm{~m}$; for a higher oceanictype lapse rate of $0.8^{\circ} \mathrm{C}$ per $100 \mathrm{~m}$, the same increase would move the tree line upwards by $\sim 125 \mathrm{~m}$ (Crawford 2001). However, such a migration in response to recent warming has not been recorded so far (Virtanen et al. 2003), although some studies suggest an acceleration of the trend in the upward shift of alpine plants since the mid-1980s (Walther et al. 2005). In the case of continued warming, while some tree encroachment into the sub-alpine zone is likely, this is unlikely to occur broadly since the altitude of tree lines in the Highlands is significantly affected by wind. Thus the interaction between local topographic characteristics and possible wind-field changes are likely to remain a more significant local control under warming scenarios for the Highlands, although there is some evidence for increased growth of established trees and shrubs and increased shrub abundance in response to recent regional warming elsewhere (Kullman 2003).

To emphasise the influence of wind on tree line in the Highlands, the $\mathrm{BL}_{\mathrm{Obs}}$ projections for Balmoral indicate the summer $10^{\circ} \mathrm{C} \mathrm{T}_{\text {mean }}$ isotherm is located at $\sim 700 \mathrm{~m}$. However, the actual tree line is generally closer to $\sim 600 \mathrm{~m}$ for eastern uplands and more continentally influenced interior regions of the Highlands (Horsfield \& Thompson 1996), although in parts of the Cairngorms, tree lines are also recorded at higher elevations. The HadRM $3 \mathrm{H}_{\mathrm{Sim}}$ projections indicate migrations of the summer $10^{\circ} \mathrm{C} \mathrm{T}$ mean isotherm to altitudes of $\sim 760$ and $\sim 830 \mathrm{~m}$ for the 2050s Low and 2050s High, respectively, for the Balmoral baseline values. However, given the limiting factor of wind, it is highly unlikely that tree lines will shift to these elevations. A more conspicuous change is likely to be the migration and expansion of alpine grasslands and dwarf-shrub heaths into higher altitudinal zones (Moen et al. 2004). With confidence in GCM- and RCM-modelled windfield outputs remaining low (Hulme et al. 2002, Woolf \& Coll 2007), the interaction of temperature, wind-field change and the influence of local topography in determining vegetation shifts requires investigation at a site scale. Certainly there are precedents for historically higher tree lines across the region; palaeoclimatic records indicate that tree lines may have been substantially higher than at present during the boreal climatic optimum of the Holocene (Grace et al. 2002).

Some monitoring studies indicate a climate-induced extirpation of high-elevation floras and a northward shift in other groupings from the late 1980s (Lesica \& McCune 2004), although other work indicates that montane pine limits appear to be stabilised by species interactions and may not respond directly to moderate climatic change (Hättenschwiler \& Körner 1995). Other processes such as soil conditions, winter desiccation, seed limitation and competition are also important (Dullinger et al. 2004). It is postulated that in the Highlands, montane habitats of moss heaths and those with arctic-alpine dwarf shrubs such as alpine bearberry Arctostaphlos alpinus and the distinctive sub-species of crowberry Empetrum nigrum hermaphroditum are expected to experience a severe decline in range size with warming (Ellis \& McGowan 2006). Similarly, populations of arctic and sub-arctic species, such as curved wood rush Luzula arcuata and drooping saxifrage Saxifraga cernua, which are restricted to altitudes above $700 \mathrm{~m}$, are expected to decline in extent (Ellis \& McGowan 2006). It is clear therefore that detailed multi-factorial and site-specific models are required, since changes driven by temperature, precipitation and wind field shifts will be superimposed upon other environmental controls, with impacts manifesting themselves at the species level.

Certainly the possible response to the more dramatic temperature changes across the altitudinal zones indicated by the HadRM3 $3 \mathrm{H}_{\text {Sim }}$ projections requires further work. Bio-climatic modelling supports the broad findings and conclusions here, e.g. that there is a significant decrease in suitable climate space for montane habitats associated with the UKCIP 2050s scenarios (Berry et al. 2005). Overall, however, the response of mountain plant species in general to climate change remains poorly understood due to a lack of accurate observational data on long-term changes and knowledge about adaptation; and our understanding of the potential impacts on ecosystem processes and biotic interactions in maritime upland regions remains limited (Ellis \& McGowan 2006). Hence there is a need for 
data acquisition on the abundance and distribution of the most climate-vulnerable montane species and their general ecology (Ellis \& Good 2005). Further bioclimatic modelling at the site scale in the Highlands supports this and indicates that, even at fine scales, climatic variables do not fully explain upland species distributions, although temperature was identified as a key controlling variable associated with possible future shifts (Trivedi et al. 2008a,b). In addition, there is a need to develop methods which will deliver more locally relevant representations of future change in key climatic variables so that land managers can make better informed decisions on stewardship of vulnerable communities and habitats.

Equally clear is that advances in modelling capability must be linked to wider policy initiatives for maritime uplands if robust climate change adaptation plans are to be implemented effectively (Orr et al. 2008, Price 2008). It is suggested that results such as those presented here can help contribute to conservation policy by delivering more locally relevant projections of change upon which adaptation decisions can be based. However, upland systems are also subject to stresses and vulnerabilities due to anthropogenic factors other than climate change, including agriculture, forestry, freshwater abstraction, tourism and recreation, infrastructure development, the introduction and expansion of alien species, and air and water pollution (Price 2008). There is also a need for ongoing and future agrienvironmental policies to be quickly adapted to protect biodiversity and ecosystem services provided by upland communities, and to assess how these can be integrated with climate change adaptation policies (Orr et al. 2008); and while many distinct areas of public policy impinge on the uplands, most have yet to integrate climate change protection within their objectives (Orr et al. 2008). Compounding these challenges, uncertainty is perhaps the single most characteristic facet of a climate scenario and one that climate science has struggled to come to terms with (Morgan et al. 2009). Arising from this, an essential component of the communication and dissemination process for climate scenarios is to convey the range of assumptions, conflicts and compromises that have been made in their construction (Hulme $\&$ Dessai 2008). The recognition that communication of uncertainty is important has been enthusiastically adopted in the new UKCP09 scenarios, and considerable effort has been made to highlight where these lie and how to interpret the probability assignations provided with the new projections (Murphy et al. 2009).

Aside from the uncertainties associated with the RCM projections of future change, results here should be interpreted cautiously due to, for example, the temperature biases associated with the LRMs. However, the work is locally relevant and the method could be extended for application at a site scale for other upland regions, provided that locally representative LRVs are applied. Since there are cold biases when $\mathrm{BL}_{\mathrm{Obs}}$ are projected via the LRMs for some seasons, this implies that shifts in the mean isotherm values associated with each zone could be greater than those reported here. There are remaining issues surrounding how the HadRM3H parameterisation schemes capture the 1961-1990 BL for the locations reported here, and more widely for the Highlands (Coll et al. 2005). These apparent systematic biases in the RCM reinforce the need for the caution advocated elsewhere in interpreting the performance of climate models (e.g. Fowler et al. 2007). There is a systematic seasonal $T_{\min }$ warm bias in some of the HadRM3H grid cells, while for $\mathrm{T}_{\text {max }}$ the warm bias associated with winter in HadRM3H grids is countered by a cold bias in spring, summer and autumn, at least for grid cells in the eastern Highlands. In addition, the use of only 1 set of climate change data for the projection of future warming effectively only propagates these biases via the LRMs.

There is much current interest among both scientists and policymakers in the development of regional scenarios for future changes in climate extremes. Therefore it is critical that the models realistically simulate all aspects of present-day climate, including climatological averages, to avoid unrealistic projected changes (Jones \& Moberg 2003). However, there is no best single model; their simulation skill for key statistics varies between, and even within, climatic variables both temporally and spatially (Fowler et al. 2007). There is also no one best approach for maritime regions. Using the alternative methodology of statistical downscaling (SD), e.g. Crawford et al. (2007) demonstrated that GCM grid box selection (as well as predictor selection) can bias results for maritime regions subject to the influence of contrasting synoptic systems. Alongside the use of data from other RCMs, the parallel application of SD may offer further utility, and the method has been applied to examine snowpack and vegetation changes at other high-altitude sites (Martin et al. 1997, Scott et al. 2003). It is therefore suggested that a refinement to the approach, linked to a wider modelling effort incorporating other important environmental controls for upland species distributions could better inform future management initiatives for the conservation sector.

\section{CONCLUSIONS AND SUGGESTIONS FOR FUTURE WORK}

Results reported here relate to the technical performance of HadRM3H, since any of the systematic biases associated with $\mathrm{BL}_{\mathrm{Sim}}$ will be incorporated in the future 
projections of change from the 2020s to the 2080s. We demonstrated that terrain-related local controls on climate such as valley heating and inversions are not fully captured in the RCM parameterisation schemes for $\mathrm{BL}_{\mathrm{Sim}}$. However, even if climate models accurately reproduce observed conditions, there has been little assessment of whether this predicates an ability in future prediction (Fowler et al. 2007). Nevertheless, it has been demonstrated that by applying a locally representative lapse rate adjustment, there is scope to better represent the range of possible future thermal climate for maritime uplands. However, the results are obviously conditional and based upon the assumptions within the LRMs themselves, as well as the wider uncertainties associated with the use of RCM output. Compounding these issues, the $\mathrm{BL}_{\mathrm{Obs}}$ values projected through the LRMs are from a decoupled valley site and may not accurately represent future warming at higher elevations in the eastern Highlands. Consequently, confidence in the validity of the future projections is limited, and an integrated effort is required from the research community if robust projections of change with altitude are to be delivered. An obvious extension of the work reported here would be to replicate and refine some of the procedures using a range of climate change outputs from different models. This would allow an exploration of e.g. whether certain combinations of $\mathrm{GCM}(\mathrm{s})$ and $\mathrm{RCM}(\mathrm{s})$ are more effective than others in explaining present upland climate conditions, and whether uncertainties associated with particular elements or seasons can be minimised based on different combinations of models.

Acknowledgements. Thanks to the UHI Millennium Institute and North Highland College for providing the funding for the $\mathrm{PhD}$ research upon which this work was based. We thank the BADC for providing the Meteorological Data and the United Kingdom Climate Impacts Programme for the climate change data; as well as J. McIlveny for supplying the high resolution digital elevation model for the UK and other GIS spatial data. We also thank U. Peterman for supplying the program used to process the station temperature records from early in the life of the project, and thank the 3 anonymous reviewers who provided valuable feedback and comments on the manuscript.

\section{LITERATURE CITED}

Barnett C, Hossell J, Perry M, Procter C, Hughes G (2006) A handbook of climate trends across Scotland. SNIFFER Project CC03, Scotland and Northern Ireland Forum for Environmental Research. Available at www.sniffer.org. uk/climatehandbook/

Beldring S, Engen-Skaugen T, Forland EJ, Roald LA (2008) Climate change impacts on hydrological processes in Norway based on two methods for transferring regional climate model results to meteorological station sites. Tellus 60:439-450

Beniston M (2003) Climatic change in mountain regions: a review of possible impacts. Clim Change 59:5-31

Berry PM, Dawson TP, Harrison PA, Pearson RG (2002) Modelling potential impacts of climate change on the bioclimatic envelope of species in Britain and Ireland. Glob Ecol Biogeogr 11:453-462

Berry PM, Harrison PA, Dawson TP, Walmsley CA (eds) (2005) Modelling natural resource responses to climate change (MONARCH). A local approach: development of a conceptual and methodological framework for universal application. UKCIP, Oxford

Birks HJB (1997) Scottish biodiversity in a historical context. In: Fleming LV, Newton AC, Vickery JA, Usher MB (eds) Biodiversity in Scotland: status, trends and initiatives. TSO Scotland, Edinburgh, p 21-35

Blandford TR, Humes KS, Harshburger BJ, Moore BC, Walden VP (2008) Seasonal and synoptic variations in near-surface air temperature lapse rates in a mountainous basin. J Appl Meteorol 47:249-261

Bradley RS, Vuille M, Diaz HF, Vergara W (2006) Threats to water supplies in the tropical Andes. Science 312: $1755-1756$

Carter TR, Hulme M, Viner D (eds) (1999) Representing uncertainty in climate change scenarios and impact studies. ECLAT-2, Rep No.1, Helsinki Workshop, 14-16 April 1999, CRU, Norwich

Coll J (2007) Local scale assessment of climate change and its impacts in the Highlands and Islands of Scotland. PhD thesis, UHI Millennium Institute/The Open University, Milton Keynes

Coll J, Gibb SW, Harrison J (2005) Modelling future climates in the Scottish Highlands-an approach integrating local climatic variables and regional climate model outputs. In: Thompson DBA, Price MF, Galbraith CA (eds) Mountains of northern Europe: conservation, management, people and nature. TSO Scotland, Edinburgh, p 103-119

Crawford RM (2001) Plant community responses to Scotland's changing environment. Bot J Scotl 53:77-105

> Crawford T, Betts NL, Favis-Mortlock D (2007) GCM grid-box choice and predictor selection associated with statistical downscaling of daily precipitation over Northern Ireland. Clim Res 34:145-160

Crawley MJ (2007). The R book. John Wiley \& Sons, Chichester

Dullinger S, Dirnbock T, Grabherr G (2004) Modelling climate change-driven treeline shifts: relative effects of temperature increase, dispersal and invasability. J Ecol 92: 241-252

European Commission (2005) Natura 2000 in the Atlantic Region. European Communities, Luxembourg

Ellis NE, Good JEG (2005) Climate change and effects on montane ecosystems: a conservation perspective. In: Thompson DBA, Price MF, Galbraith CA (eds) Mountains of northern Europe: conservation, management, people and nature. TSO Scotland, Edinburgh, p 103-119

Ellis N, McGowan G (2006) Climate change. In: Shaw TP, Thompson DBA (eds) The nature of the Cairngorms: diversity in a changing environment. The Stationery Office, Edinburgh, p 353-365

Engen-Skaugen T (2007) Refinement of dynamically downscaled precipitation and temperature scenarios. Clim Change 84:365-382

Fischlin A, Midgley GF, Price JT, Leemans R and others (2007) Ecosystems, their properties, goods, and services. In: Parry ML, Canziani OF, Palutikof JP, van der Linden PJ, Hanson CE (eds) Climate change 2007: impacts, adaptation and vulnerability. Contribution of Working Group II to the 4 th assessment report of the Intergovernmental 
Panel on Climate Change. Cambridge University Press, Cambridge, p 211-272

Fowler HJ, Kilsby CG (2007) Using regional climate model data to simulate historical and future river flows in northwest England. Clim Change 80:337-367

Fowler HJ, Ekstrom M, Kilsby CG, Jones PD (2005) New estimates of future changes in extreme rainfall across the UK using regional climate model integrations. 1. Assessment of control climate. J Hydrol (Amst) 300:212-233

Fowler HJ, Blenkinsop S, Tebaldi C (2007) Linking climate change modelling to impacts studies: recent advances in downscaling techniques for hydrological modelling. Int $\mathrm{J}$ Climatol 27:1547-1578

> Gordon C, Cooper C, Senior CA, Banks H, Gregory JM, Johns TC, Mitchell JFB, Wood RA (2000) The simulation of SST, sea ice extents and ocean heat transports in a version of the Hadley Centre coupled model without flux adjustments. Clim Dyn 16:147-168

> Grace J, Berninger F, Nagy L (2002) Impacts of climate change on the tree line. Ann Bot (Lond) 90:537-544

> Groisman PY, Knight RW, Easterling D, Karl TR, Hegerl GC, Razuvaev VN (2005) Trends in intense precipitation in the climate record. J Clim 18:1326-1350

Harding RJ (1978) The variation of the altitudinal gradient of temperature within the British Isles. Geogr Ann 60:43-49

Harlow RC, Burke EJ, Scott RL, Shuttleworth WJ, Brown CM, Petti JR (2004) Derivation of temperature lapse rates in semi-arid south-eastern Arizona. Hydrol Earth Syst Sci 8: 1179-1185

Harrison SJ (1994) Air temperatures in the Ochil Hills, Scotland: problems with paired stations. Weather 49:209-215

Harrison SJ, Kirkpatrick AH (2001) Climatic change and its potential implications for environments in Scotland. In: Gordon JE, Leys KF (eds) Earth science and the natural heritage: interactions and integrated management. TSO Scotland, Edinburgh, p 296-305

> Hättenschwiler S, Körner C (1995) Responses to recent climate warming of Pinus sylvestris and Pinus cembra within their montane transition zone in the Swiss Alps. J Veg Sci 6:357-368

Hill MO, Downing TE, Berry PM, Coppins BJ and others (1999) Climate changes and Scotland's natural heritage: an environmental audit. Survey and Monitoring Report No. 132, Scottish Natural Heritage, Edinburgh

Holden J, Adamson JK (2002) The Moor House long-term upland temperature record: new evidence of recent warming. Weather 57:119-127

Horsfield D, Thompson DBA (1996) The Uplands: guidance on terminology regarding altitudinal zonation and related terms. Information and Advisory Note No. 26. Scottish Natural Heritage, Battleby

> Hulme M, Dessai S (2008) Negotiating future climates for public policy: a critical assessment of the development of climate scenarios for the UK. Environ Sci Policy 11:54-70

Hulme M, Jenkins JG, Lu X, Turnpenny JR and others (2002) Climate change scenarios for the United Kingdom: the UKCIP02 scientific report. Tyndall Centre for Climate Change Research, School of Environmental Sciences, University of East Anglia, Norwich

Jones PD, Moberg A (2003) Hemispheric and large-scale surface air temperature variations: an extensive review and an update to 2001. J Clim 16:206-213

Jump AS, Hunt JM, Penuelas J (2007) Climate relationships of growth and establishment across the altitudinal range of Fagus sylvatica in the Montseny Mountains, northeast Spain. Ecoscience 14:507-518

Klanderud K, Birks HJB (2003) Recent increases in species richness and shifts in altitudinal distributions of Norwegian mountain plants. Holocene 13:1-6

Klasner FL, Fagre DB (2002) A half century of change in alpine treeline patterns at Glacier National Park, Montana, USA. Arct Antarct Alp Res 34:49-56

Koppen W (1931) Grundriss der Klimakunde. De Gruyer, Berlin

Kullman L (2002) Rapid recent range-margin rise of tree and shrub species in the Swedish Scandes. J Ecol 90:68-77

Kullman L (2003) Recent reversal of Neoglacial climate cooling trend in the Swedish Scandes as evidenced by mountain birch tree-limit rise. Glob Planet Change 36:77-88

$>$ Lean JL, Rind DH (2009) How will Earth's surface temperature change in future decades? Geophys Res Lett 36: L15708 doi:10.1029/2009GL038932

> Lesica P, McCune B (2004) Decline of arctic-alpine plants at the southern margin of their range following a decade of climatic warming. J Veg Sci 15:679-690

Lundquist JD, Cayan DR (2007) Surface temperature patterns in complex terrain: daily variations and long-term change in the central Sierra Nevada, California. J Geophys Res 112:D11124 doi:10.1029/2006JD007561

MacDonald GM, Case RA, Szeicz JM (1998) A 538-year record of climate and treeline dynamics from the Lower Lena River Region of Northern Siberia, Russia. Arct Antarct Alp Res 30:334-339

Malby AR, Whyatt JD, Timmis R, Wilby RL, Orr HG (2007) Forcing of orographic rainfall and rainshadow processes by climate change: analysis and implications in the English Lake District. Hydrol Process 52:276-291

- Maraun D, Osborn TJ, Gillett NP (2008) United Kingdom daily precipitation intensity: improved early data, error estimates and an update from 2000 to 2006. Int J Climatol 28:833-842

Martin E, Timbal B, Brun E (1997) Downscaling of general circulation model outputs: simulation of the snow climatology of the French Alps and sensitivity to climate change. Clim Dyn 13:45-56

> McClatchey J (1996) Spatial and altitudinal gradients of climate in the Cairngorms - observations from climatological and automatic weather stations. Bot J Scotl 48:31-49

Moen J, Aune K, Edenius L, Angerbjorn A (2004) Potential effects of climate change on treeline position in the Swedish mountains. Ecol Soc 9:16

Morgan MG, Dowlatabadi H, Henrion M, Keith D, Lempert R, McBride S, Small M, Wilbanks T (2009) Best practice approaches for characterizing, communicating and incorporating scientific uncertainty in climate decision making. US Climate Change Science Program, National Oceanic and Atmospheric Administration, Washington, DC

Murphy JM, Sexton DMH, Jenkins GJ, Boorman PM and others (2009) UK climate projections science report: climate change projections. Met Office Hadley Centre, Exeter

> Nogués-Bravo D, Araujo MB, Errea MP, Martinez-Rica J (2007) Exposure of global mountain systems to climate warming during the 21st Century. Glob Environ Change $17: 420-428$

Orr HG, Wilby RL, McKenzie Hedger M, Brown I (2008) Climate change in the uplands: a UK perspective on safeguarding regulatory ecosystem services. Clim Res 37: 77-98

Pages M, Miro JR (2010) Determining temperature lapse rates over mountain slopes using vertically weighted regression: a case study from the Pyrenees. Meteorol Appl 17: 53-63

$>$ Pepin NC (1995) The use of GCM scenario output to model effects of future climatic change on the thermal climate of 
marginal maritime uplands. Geogr Ann 77:167-185

Pepin NC (2001) Lapse rate changes in northern England. Theor Appl Climatol 68:1-16

Pepin NC (2010) Changing climate at high elevation stations: a global perspective. Proc Global Change and the World's Mountains, Perth, UK, September 26-30 2010, Parallel Sesson 3.1 (Abstract) (in press)

Pepin NC, Lundquist J (2008) Temperature trends at high elevations: patterns across the globe. Geophys Res Lett 35: L14701 doi:10.1029/ 2008GL034026

Pepin NC, Seidel DJ (2005) A global comparison of surface and free-air temperatures at high elevations. J Geophys Res 110:D03104 doi:10.1029/2004JD005047

Pope VD, Galliani ML, Rowntree PR, Stratton RA (2000) The impact of new physical parameterisations in the Hadley Centre climate model-HadAM3. Clim Dyn 16:123-146

Price MF (2008) Maintaining mountain biodiversity in an era of climate change. In: Borsdorf A, Stötter J, Veulliet E (eds) Managing alpine future. Proc Innsbruck Conf October 15-17, 2007. Austrian Academy of Sciences Press, Vienna, p 17-33

Ratcliffe DA (1977) A nature conservation review, Vol 1. Cambridge University Press, Cambridge

Ratcliffe DA, Thompson DBA (1988) The British Uplands; their ecological importance and international significance. In: Ratcliffe DA, Thompson DBA (eds) Ecological change in the uplands. Br Ecol Soc Spec Publ 7. Blackwell Scientific Publications, Oxford, p 3-36

Rolland C (2003) Spatial and seasonal variations of air temperature lapse rates in alpine regions. J Clim 16: 1032-1046

Scott D, McBoyle G, Mills B (2003) Climate change and the skiing industry in southern Ontario (Canada): exploring the importance of snowmaking as a technical adaptation. Clim Res 23:171-181

Submitted: November 10, 2009; Accepted: October 19, 2010
Thomas CD, Cameron, A, Green RE, Bakkenes M and others (2004) Extinction risk from climate change. Nature 427: $145-148$

Thompson DBA, Nagy L, Johnson SM, Robertson P (2005) The nature of mountains: an introduction to science, policy and management issues. In: Thompson DBA, Price MF, Galbraith CA (eds) Mountains of northern Europe: conservation, management, people and nature. TSO Scotland, Edinburgh, p 43-56

Thompson R, Ventura M, Camarero L (2009) On the climate and weather of mountain and sub arctic lakes in Europe and their susceptibility to future climate change. Freshw Biol 54:2433-2451

> Trivedi MR, Morecroft MD, Berry PM, Dawson TP (2008a) Potential effects of climate change on plant communities in three montane nature reserves in Scotland, UK. Biol Conserv 141:1665-1675

> Trivedi MR, Berry PM, Morecroft MD, Dawson TP (2008b) Spatial scale affects bioclimate model projections of climate change impacts on mountain plants. Glob Change Biol 14:1089-1103

Virtanen R, Eskelinen E, Gaare E (2003) Long-term changes in alpine plant communities in Norway and Finland. In: Nagy L, Grabherr G, Korner C, Thompson DBA (eds) Alpine biodiversity in Europe. Springer-Verlag, Berlin, p 411-422

> Walther BR, Beissner S, Burga CA (2005) Trends in the upward shift of alpine plants. J Veg Sci 16:541-548

Wearne LJ, Morgan JW (2001) Recent forest encroachment into subalpine grasslands near Mount Hotham, Victoria, Australia. Arct Antarct Alp Res 33:369-377

Woolf D, Coll J (2007) Impacts of climate change on storms and waves. In: Buckley PJ, Dye, SR, Baxter JM (eds) Marine climate change impacts annual report card 2007. MCCIP, Lowestoft, Available at www.mccip.org.uk

Proofs received from author(s): December 14, 2010 